\title{
PENINGKATAN KETERAMPILAN MENULIS PUISI DENGAN METODE MIND MAPPING PADA SISWA KELAS VIII D SMP NEGERI 5 BANGUNTAPAN BANTUL DAERAH ISTIMEWA YOGYAKARTA
}

\author{
SITI ZUKHANAH \\ SMP Negeri 5 Banguntapan Bantul, Yogyakarta \\ e-mail : zukha.zahra@gmail.com
}

\begin{abstract}
ABSTRAK
Penelitian ini bertujuan untuk menggambarkan peningkatan kualitas hasil belajar dan belajar menulis puisi pada siswa kelas VIII D SMP Negeri 5 Banguntapan Bantul dengan menggunakan metode mind mapping. Penelitian ini menggunakan pendekatan Classroom Action Research dengan teknik pengumpulan data menggunakan observasi, wawancara, catatan lapangan, kuesioner, dan analisis dokumen. Analisis data dalam penelitian ini menggunakan analisis deskriptif komparatif dan analisis kritis. Proses penelitian dilakukan dalam dua siklus dengan empat tahap dalam setiap siklus. Berdasarkan temuan penelitian, dapat disimpulkan bahwa: (1) metode pemetaan pikiran dapat meningkatkan kualitas belajar menulis puisi. Hal ini terlihat dari peningkatan ke aktif, perhatian, konsentrasi, antusiasme, dan keseriusan siswa dalam belajar (2) dengan menggunakan metode mind mapping keterampilan menulis puisi siswa dapat ditingkatkan. Hal ini ditunjukkan dengan peningkatan nilai rata-rata penulisan puisi siswa. Skor rata-rata siswa yang menulis puisi dalam pra-aksi adalah 15,04, dan tingkat kelengkapan klasik adalah 43\%. Pada siklus pertama meningkat menjadi 19,14, dan kelengkapan klasik adalah 67,8\%. Pada siklus kedua meningkat menjadi 20,54, dan 85,7\% kelengkapan klasik.
\end{abstract}

Key words: Writing Skills, Mind Mapping Method, Poetry.

\section{PENDAHULUAN}

Kegiatan komunikasi bahasa dapat dijabarkan menjadi empat keterampilan berbahasa yakni keterampilan membaca (reading), mendengarkan (listening), berbicara (speaking), dan menulis (writing).

Menulis merupakan salah satu hasil siswa dalam proses pembelajaran, dan keterampilan ini masuk dalam ranah psikomotor. Menulis merupakan suatu kegiatan yang produktif dan ekspresif. Dalam kegiatan ini, penulis haruslah terampil memanfaatkan grafologi, struktur bahasa, dan kosa kata. Dalam pembelajaran bahasa Indonesia di sekolah, penting bagi siswa pandai dalam menulis. Hal itu disebabkan karena menulis merupakan suatu keterampilan berbahasa yang digunakan untuk berkomunikasi secara tidak langsung, tidak secara tatap muka dengan orang lain (Tarigan, 2008: 3-4)

Pada Kurikulum 2013 mata pelajaran Bahasa yang sebelumnya lebih cenderung ditekankan pada sarana komunikasi, kini juga ditekankan sebagai sarana pengembangan kemampuan berpikir. Pembelajaran bahasa Indonesia yang berbasis teks pada Kurikulum 2013 bertujuan untuk menjadikan bahasa sebagai sarana berpikir, santun makna. Pikiran, gagasan, pesan, atau konsep secara utuh, hanya ditemukan dalam teks yang berwujud teks tertulis atau pun lisan. Pendekatan ilmiah yang diterapkan dalam pembelajaran bahasa Indonesia pada kurikulum baru ini diyakini sebagai titian emas perkembangan dan pengembangan sikap, pengetahuan, serta keterampilan peserta didik (Kemendikbud, 2013:165).

Pembelajaran menulis dalam Kurikulum 2013 menjadi keterampilan berbahasa yang diutamakan selain keterampilan membaca. Keterampilan menulis merupakan hasil cipta yang produktif dari proses membaca, mendengarkan, dan berbicara. Melalui kegiatan menulis inilah peserta didik dapat mengungkapkan gagasannya kepada orang lain secara tidak langsung. 
Sayuti (2002:12) mengemukakan bahwa keterampilan menulis puisi wajib dimiliki oleh siswa sebagai suatu keterampilan yang aktif dan produktif untuk mengungkapkan ide, pikiran, gagasan, pengetahuan, ilmu, dan pengalaman. Pembelajaran menulis puisi di sekolah bertujuan untuk menanamkan rasa peka terhadap karya sastra, sehingga memunculkan perasaan senang, cinta dan tertarik terhadap apresiasi sastra.

Selain itu, pembelajaran menulis puisi di sekolah sangat penting dan bermanfaat bagi siswa karena dapat menstimulus otak sehingga siswa mampu berfikir kreatif dan simpatik terhadap lingkungan di sekitarnya, mengembangkan kreativitas, menanamkan keberanian dan percaya diri, dan membantu siswa menuangkan ide, pikiran, pengalaman, perasaan dan cara memandang kehidupan. Melihat banyaknya manfaat yang akan diperoleh siswa dalam pembelajaran menulis, seharusnya kegiatan menulis puisi menjadi kegiatan yang diminati siswa. Akan terapi, kondisi realitas pada sekolah kami menunjukkan bahwa menulis menjadi kegiatan yang masih sulit dan tidak menarik bagi siswa.

Hal serupa terjadi dalam pembelajaran menulis puisi di kelas VIII D SMP Negeri 5 Banguntapan. Pembelajaran menulis puisi masih didominasi teori yang berhubungan dengan puisi dari pada praktik menulis puisi. Keterampilan menulis siswa tidak terkembangkan dengan baik. Hal ini tercermin dari perolehan nilai menulis puisi siswa. Dari 28 siswa, hanya 12 siswa yang mencapai nilai di atas KKM (Kriteria Ketuntasan Minimal) yaitu 75, sedangkan 16 siswa masih mencapai nilai di bawah KKM. Hal ini berarti hanya 43\% ketuntasan belajar untuk kelas tersebut. Dari hasil pre test menulis puisi diketahui bahwa siswa siswa masih kurang mampu memilih kata-kata yang tepat sesuai tema, kurang mampu menggunakan bahasa kias dengan baik, dan kurang mampu memilih judul dan tema yang sesuai dengan isi puisi.

Dari segi proses, guru belum menemukan metode yang tepat dalam membelajarkan kompetensi dasar menulis puisi. Langkah-langkah pembelajaran masih cenderung berpusat pada guru dan kurang variatif. Guru juga belum menggunakan media, dan sumber belajar yang variatif. Hal ini mempengaruhi keaktifan siswa. Siswa menjadi jenuh dan terlihat tidak bergairah dalam belajar. Dari pihak siswa diketahui bahwa kesulitan siswa dalam menulis puisi adalah menemukan ide dan memilih kata-kata yang sesuai dengan isi puisi. Ketika diberi tugas oleh guru untuk menulis puisi, mereka lebih banyak menggunakan waktu untuk memikirkan tentang apa yang akan ditulis . Mereka kesulitan untuk memulai menulis. Kalau pun mereka sudah menemukan ide, beberapa siswa menyatakan sulit memilih kata-kata yang sesuai dengan tema yang telah dipilih.Untuk menyikapi permasalahan tersebut diperlukan suatu metode pembelajaran yang dapat membantu siswa dalam mengatasi kesulitan-kesulitan yang dihadapi ketika belajar menulis puisi. Diharapkan melalui peningkatan kualitas proses pembelajaran, hasil pembelajaran berupa keterampilan menulis puisi siswa pun meningkat.

Berakar dari kesulitan siswa dalam menulis puisi yaitu memunculkan ide dan memilih kata sesuai dengan tema maka dipilih metode Mind Mapping. Metode Mind Mapping akan membantu siswa dalam memilih kata-kata yang sesuai dengan tema puisi. Dengan mind mapping mempermudah siswa memilih kata-kata yang sesuai dengan ide atau tema puisi yang ditulis.Siswa akan kreatif menemukan kata-kata yang ada hubungannya dengan tema yang dipilih sebagai titik sentral. Siswa juga akan kreatif mengembangkan kata-kata berikutnya sebagai cabang dari poin-poin penting tema utamanya. Selanjutnya dari kumpulan kata-kata yang berhubungan satu sama lain tersebut siswa menyusun dan mengkreasikan menjadi sebuah puisi yang padu dan indah.

Hipotesis dalam penelitian ini adalah; 1) Melalui metode Mind Mapping dapat meningkatkan kualitas pembelajaran menulis puisi di kelas VIII D SMP Negeri 5 Banguntapan tahun pelajaran 2019/2020, 2) Melalui metode Mind Mapping dapat meningkatkan kualitas keterampilan menulis puisi siswa kelas VIII D SMP Negeri 5 Banguntapan tahun pelajaran 2019/2020. 


\section{METODE PENELITIAN}

Penelitian ini dilaksanakan dengan pendekatan penelitian kualitatif dengan strategi Penelitian Tindakan Kelas (PTK). Bentuk siklus yang digunkan dalam penelitian ini menggunakan model Kemmis dan McTaggrat. Siklus ini tidak hanya berlangsung satu kali, tetapi beberapa kali hingga tercapai tujuan yang diharapkan. Dalam pelaksanaannya peneliti mulai dari fase refleksi awal untuk melakukan studi pendahuluan sebagai dasar dalam merumuskan masalah penelitian. Selanjutnya diikuti perencanaan, tindakan, observasi, dan refleksi, (Arikunto, 2008:16).

Subjek penelitian ini adalah siswa kelas VIII D SMP Negeri 5 Banguntapan Bantul tahun ajaran 2019/2020, yang berjumlah 28 siswa. Objek dalam penelitian ini adalah keterampilan dmenulis puisi siswa dengan menggunakan mind mapping. Pengumpulan data dalam penelitian ini menggunakan teknik observasi, tes, catatan lapangan, wawancara, angket, dan dokumentasi. Sedangkan analisis data yang digunakan dalam penelitian ini adalah:

(1) Analisis Data Aktivitas Siswa dalam Pembelajaran.

Data hasil observasi yang didapat melalui lembar observasi aktivitas siswa digunakan untuk melihat proses dan perkembangan aktivitas yang terjadi selama pembelajaran berlangsung. Data jumlah siswa yang terlibat dalam masing-masing aktivitas dipersentasekan dengan rumus :

$$
P=\frac{F}{N} X 100
$$

Keterangan:

$\mathrm{P}=$ Angka persentase Aktivitas

$\mathrm{F}=$ Frekuensi Aktivitas siswa

$\mathrm{N}=$ Jumlah siswa.

(2) Analisis Data Ketuntasan Belajar ( Tes )

Data hasil belajar siswa yang diperoleh dari tes yang dilaksanakan setelah berakhir satu siklus dianalisis untuk melihat ketuntasan belajar siswa secara individu. Seorang siswa akan dikatakan tuntas apabila nilai siswa telah memenuhi Kriteria Ketuntasan Minimal (KKM). KKM yang ditetapkan yaitu 75. Dalam penelitian ini hasil belajar siswa yang memenuhi nilai KKM dapat melebihi $80 \%$ dari jumlah siswa. Ketuntasan belajar siswa secara individu dapat dihitung dengan menggunakan rumus

$$
N I=\frac{T}{S M} \times 100 \%
$$

Keterangan:

$\mathrm{NI}=$ Ketuntasan belajar secara individu

$\mathrm{T}=$ Skor yang diperoleh siswa

$\mathrm{SM}=$ Skor maksimum dari tes

Siswa dikatakan tuntas jika NI $\quad \geq 75 \%$

Indikator kinerja dalam penelitian ini terdiri atas indikator keberhasilan proses dan indikator keberhasilan produk. Indikator keberhasilan proses dalam penelitian ini adalah apabila pembelajaran menulis puisi menarik dan menyenangkan sehingga siswa berperan aktif dalam proses pembelajaran.Indikator keberhasilan dalam penelitian tindakan ini adalah apabila skor rata-rata keterampilan menulis puisi siswa secara individu sudah mencapai KKM yaitu 75, dan secara klasikal 80\% siswa sudah mencapai KKM.

\section{HASIL DAN PEMBAHASAN HASIL PENELITIAN}

Berdasarkan data pengamatan proses pembelajaran menulis puisi pada observasi awal diketahui: (1) aspek keaktifan dengan jumlah siswa aktif 10 siswa (35,7\%) dengan kategori kurang, (2) aspek perhatian dan dan konsentrasi siswa dengan jumlah 10 siswa $(35,7 \%)$ dengan kategori kurang, (3) aspek minat siswa dalam pembelajaran dengan jumlah 8 siswa ( $28,6 \%$ ) dengan kategori kurang, dan (4) aspek keseriusan siswa saat kegiatan menulis 
puisi dengan jumlah 13 siswa ( 46,4\%) dengan kategori cukup. Selain itu, Berdasarkan hasil penilaian keterampilan siswa dalam menulis puisi masih rendah. Skor rata-rata menulis puisi siswa secara keseluruhan adalah 15,04 atau $60 \%$.

Siklus I dilaksanakan hari Rabu,11 September 2019 dan Jumat, 13 September 2019. Pengamatan terhadap aktivitas siswa kelas VIII D dalam kegiatan menulis puisi mengalami sejumlah peningkatan terhadap 4 aspek pengamatan yaitu: aspek keaktifan dengan jumlah siswa aktif 17 siswa $(60,7 \%)$ dengan kategori baik, aspek perhatian dan konsentrasi siswa dengan jumlah siswa aktif 19 siswa $(67,9 \%)$ dengan kategori baik, aspek antusias siswa dalam pembelajaran dengan jumlah siswa aktif 15 siswa $(53,6 \%)$ dengan kategori cukup, dan aspek keseriusan siswa saat kegiatan menulis puisi dengan jumlah siswa aktif 19 siswa $(67,9 \%)$ dengan kategori baik, seperti terlihat dalam tabel berikut:

Tabel 1. Hasil Pengamatan Aktivitas Siswa pada Pembelajaran Menulis Puisi Siklus I

\begin{tabular}{|c|l|c|c|l|}
\hline \multirow{2}{*}{ No } & \multicolumn{1}{|c|}{ Aspek } & \multicolumn{2}{|c|}{$\begin{array}{l}\text { Hasil Pengamatan dalamPersentase } \\
\text { Hitungan Jumlah siswa }\end{array}$} & Kategori \\
& & 17 & \\
\hline 1. & Keaktifan & 19 & 60.7 & Baik \\
\hline 2. & $\begin{array}{l}\text { Perhatian dan } \\
\text { Konsentrasi Siswa }\end{array}$ & 15 & 67.9 & Baik \\
\hline 3. & $\begin{array}{l}\text { Antusias siswa dalam } \\
\text { pembelajaran }\end{array}$ & 19 & 53.6 & Cukup \\
\hline 4. & $\begin{array}{l}\text { Keseriusan siswa saat } \\
\text { kegiatan menulis puisi }\end{array}$ & 19 & 67.9 & Baik \\
\hline
\end{tabular}

Berdasarkan pengamatan terhadap hasil menulis puisi siswa pada siklus I dapat diketahui bahwa pemerolehan skor terendah adalah adalah 14. Sedangkan nilai tertinggi dengan jumlah skor 23. Nilai rata-rata keterampilan menulis puisi siswa dengan penerapan metode mind mapping pada siklus I sebesar 19,14 atau 77\% dan Ketuntasan klasikal 67,8\%.

Tabel 2. Hasil Keterampilan Menulis Puisi Siswa dengangunakan Metode Mind Mapping pada Siklus I

\begin{tabular}{|c|c|c|c|c|c|c|c|}
\hline \multirow[b]{2}{*}{ NAMA } & \multicolumn{6}{|c|}{ Aspek yang Dinilai } & \multirow[b]{2}{*}{ Ketuntasan } \\
\hline & $\begin{array}{c}\text { Kesatuan } \\
\text { Makna }\end{array}$ & Diksi & Persajakan & $\begin{array}{c}\text { Gaya } \\
\text { bahasa }\end{array}$ & $\begin{array}{c}\text { Pencitra } \\
\text { an }\end{array}$ & $\begin{array}{l}\text { Jml } \\
\text { Skor }\end{array}$ & \\
\hline $\mathrm{S} 1$ & 3 & 3 & 3 & 2 & 4 & 15 & Blm Tuntas \\
\hline S2 & 4 & 3 & 4 & 4 & 4 & 19 & Tuntas \\
\hline S3 & 4 & 3 & 4 & 4 & 4 & 19 & Tuntas \\
\hline S4 & 4 & 3 & 4 & 3 & 4 & 18 & Blm Tuntas \\
\hline S5 & 4 & 2 & 3 & 2 & 3 & 14 & Blm Tuntas \\
\hline S6 & 4 & 3 & 4 & 4 & 4 & 19 & Tuntas \\
\hline S7 & 4 & 3 & 4 & 4 & 4 & 19 & Tuntas \\
\hline S8 & 4 & 4 & 5 & 4 & 5 & 22 & Tuntas \\
\hline S9 & 4 & 3 & 4 & 5 & 4 & 20 & Tuntas \\
\hline S10 & 4 & 4 & 4 & 4 & 4 & 20 & Tuntas \\
\hline S11 & 5 & 4 & 4 & 4 & 5 & 22 & Tuntas \\
\hline $\mathrm{S} 12$ & 3 & 3 & 3 & 4 & 4 & 17 & Blm Tuntas \\
\hline S13 & 5 & 4 & 4 & 4 & 5 & 22 & Tuntas \\
\hline S14 & 5 & 4 & 4 & 4 & 4 & 21 & Tuntas \\
\hline
\end{tabular}




\begin{tabular}{||l|c|c|c|c|c|c|l||} 
S15 & 4 & 4 & 4 & 3 & 4 & 19 & Tuntas \\
\hline S16 & 4 & 3 & 4 & 3 & 3 & 17 & Blm Tuntas \\
\hline S17 & 4 & 3 & 4 & 4 & 4 & 19 & Tuntas \\
\hline S18 & 4 & 2 & 3 & 3 & 3 & 15 & Blm Tuntas \\
\hline S19 & 4 & 5 & 5 & 4 & 4 & 22 & Tuntas \\
\hline S20 & 4 & 3 & 4 & 4 & 5 & 20 & Tuntas \\
\hline S21 & 5 & 5 & 4 & 4 & 5 & 23 & Tuntas \\
\hline S22 & 4 & 3 & 3 & 3 & 4 & 17 & Blm Tuntas \\
\hline S23 & 4 & 3 & 4 & 4 & 4 & 19 & Tuntas \\
\hline S24 & 5 & 4 & 4 & 4 & 4 & 21 & Tuntas \\
\hline S25 & 4 & 3 & 4 & 3 & 4 & 18 & Blm Tuntas \\
\hline S26 & 5 & 4 & 4 & 4 & 5 & 22 & Tuntas \\
\hline S27 & 5 & 4 & 5 & 4 & 4 & 22 & Tuntas \\
\hline S28 & 3 & 3 & 3 & 3 & 3 & 15 & Blm Tuntas \\
\hline $\begin{array}{l}\text { JUML } \\
\text { AH }\end{array}$ & 116.00 & 95.00 & 109.00 & 102.00 & 114.00 & 536 & \\
\hline $\begin{array}{l}\text { RATA- } \\
\text { RATA }\end{array}$ & 4.14 & 3.39 & 3.89 & 3.64 & 4.07 & 19.1 & 4 \\
\hline $\begin{array}{l}\text { Present } \\
\text { ase (\%) }\end{array}$ & $83 \%$ & $68 \%$ & $78 \%$ & $73 \%$ & $81 \%$ & $77 \%$ & $67,8 \%$ \\
\hline \hline
\end{tabular}

Pada siklus II , pengamatan terhadap aktivitas siswa kelas VIII D dalam kegiatan menulis puisi mengalami sejumlah peningkatan terhadap 4 aspek pengamatan yaitu: aspek keaktifan dengan jumlah siswa aktif 20 siswa $(70,4 \%)$ dengan kategori baik, aspek perhatian dan konsentrasi siswa dengan jumlah siswa aktif 24 siswa $(85,7 \%)$ dengan kategori baik sekali, aspek antusias siswa dalam pembelajaran dengan jumlah 22 siswa $(78,6 \%)$ dengan kategori baik, dan aspek keseriusan siswa saat kegiatan menulis puisi dengan jumlah 23 siswa $(82,1 \%)$ dengan kategori baik. Aktivitas belajar siswa pada siklus II dapat dilihat pada tabel berikut:

Tabel 3. Hasil Pengamatan Aktivitas Siswa pada Pembelajaran Menulis Puisi Siklus II

\begin{tabular}{|c|l|c|c|l|}
\hline No & \multicolumn{1}{|c|}{ Aspek } & $\begin{array}{c}\text { Hasil Pengamatan dalam } \\
\text { Hitungan Jumlah siswa }\end{array}$ & $\begin{array}{c}\text { Persenta } \\
\text { se (\%) }\end{array}$ & Kategori \\
\hline 1. & Keaktifan & 20 & 71.4 & Baik \\
\hline 2. & $\begin{array}{l}\text { Perhatian dan Konsentrasi } \\
\text { Siswa }\end{array}$ & 24 & 85.7 & $\begin{array}{l}\text { Baik } \\
\text { Sekali }\end{array}$ \\
\hline 3. & $\begin{array}{l}\text { Antusias siswa dalam } \\
\text { pembelajaran }\end{array}$ & 22 & 78.6 & Baik \\
\hline 4. & $\begin{array}{l}\text { Keseriusan siswa saat } \\
\text { kegiatan menulis puisi }\end{array}$ & 23 & 82.1 & $\begin{array}{l}\text { Baik } \\
\text { sekali }\end{array}$ \\
\hline
\end{tabular}

Pengamatan terhadap hasil menulis puisi siswa pada siklus II dapat diketahui bahwa pemerolehan skor terendah adalah adalah 16. Sedangkan nilai tertinggi dengan jumlah skor 24. Nilai rata-rata keterampilan menulis puisi siswa dengan penerapan metode mind mapping pada siklus II sebesar 20,54 atau 82\% dengan ketuntasan klasikal 85,7\%. Hasil menulis puisi siswa pada siklus II dapat dilihat melalui tabel berikut ini: 
Tabel 4. Hasil Keterampilan Menulis Puisi Siswa dengan Menggunakan Metode Mind Mapping pada Siklus II

\begin{tabular}{|c|c|c|c|c|c|c|c|c|}
\hline \multirow[b]{2}{*}{ NO } & \multirow[b]{2}{*}{ NAMA } & \multicolumn{6}{|c|}{ Aspek yang Dinilai } & \multirow{2}{*}{$\begin{array}{c}\text { Ketuntasa } \\
\mathrm{n}\end{array}$} \\
\hline & & $\begin{array}{c}\text { Kesatuan } \\
\text { Makna }\end{array}$ & Diksi & $\begin{array}{l}\text { Persa- } \\
\text { jakan }\end{array}$ & $\begin{array}{c}\text { Gaya } \\
\text { bahasa }\end{array}$ & $\begin{array}{l}\text { Pencitra } \\
\text { an }\end{array}$ & $\begin{array}{l}\text { Jml } \\
\text { Skor }\end{array}$ & \\
\hline 1 & $\mathrm{~S} 1$ & 3 & 3 & 4 & 3 & 4 & 17 & $\begin{array}{c}\text { Blm } \\
\text { Tuntas }\end{array}$ \\
\hline 2 & S2 & 4 & 4 & 4 & 4 & 5 & 21 & Tuntas \\
\hline 3 & S3 & 5 & 5 & 4 & 4 & 5 & 23 & Tuntas \\
\hline 4 & S4 & 4 & 4 & 4 & 3 & 5 & 20 & Tuntas \\
\hline 5 & S5 & 5 & 4 & 3 & 4 & 4 & 20 & Tuntas \\
\hline 6 & S6 & 4 & 4 & 4 & 4 & 5 & 21 & Tuntas \\
\hline 7 & S7 & 5 & 3 & 4 & 4 & 5 & 21 & Tuntas \\
\hline 8 & S8 & 4 & 5 & 5 & 5 & 5 & 24 & Tuntas \\
\hline 9 & S9 & 5 & 4 & 4 & 5 & 4 & 22 & Tuntas \\
\hline 10 & $\mathrm{~S} 10$ & 4 & 4 & 4 & 4 & 4 & 20 & Tuntas \\
\hline 11 & $\mathrm{~S} 11$ & 5 & 4 & 5 & 5 & 5 & 24 & Tuntas \\
\hline 12 & $\mathrm{~S} 12$ & 4 & 4 & 5 & 4 & 4 & 21 & Tuntas \\
\hline 13 & $\mathrm{~S} 13$ & 5 & 4 & 5 & 4 & 5 & 23 & Tuntas \\
\hline 14 & S14 & 5 & 4 & 4 & 4 & 4 & 21 & Tuntas \\
\hline 15 & S15 & 4 & 3 & 5 & 3 & 4 & 19 & Tuntas \\
\hline 16 & $\mathrm{~S} 16$ & 4 & 3 & 4 & 3 & 3 & 17 & $\begin{array}{c}\text { Blm } \\
\text { Tuntas }\end{array}$ \\
\hline 17 & S17 & 4 & 4 & 5 & 4 & 4 & 21 & Tuntas \\
\hline 18 & S18 & 5 & 4 & 3 & 4 & 3 & 19 & Tuntas \\
\hline 19 & S19 & 4 & 4 & 5 & 4 & 4 & 21 & Tuntas \\
\hline 20 & $\mathrm{~S} 20$ & 4 & 4 & 4 & 5 & 4 & 21 & Tuntas \\
\hline 21 & $\mathrm{~S} 21$ & 5 & 4 & 4 & 4 & 5 & 22 & Tuntas \\
\hline 22 & $\mathrm{~S} 22$ & 5 & 3 & 3 & 3 & 4 & 18 & $\begin{array}{c}\text { Blm } \\
\text { Tuntas }\end{array}$ \\
\hline 23 & $\mathrm{~S} 23$ & 4 & 4 & 4 & 4 & 4 & 20 & Tuntas \\
\hline 24 & $\mathrm{~S} 24$ & 5 & 4 & 4 & 4 & 4 & 21 & Tuntas \\
\hline 25 & $\mathrm{~S} 25$ & 4 & 4 & 4 & 4 & 5 & 21 & Tuntas \\
\hline 26 & S26 & 4 & 4 & 4 & 4 & 5 & 21 & Tuntas \\
\hline 27 & S27 & 4 & 4 & 4 & 4 & 4 & 20 & Tuntas \\
\hline \multirow[t]{4}{*}{28} & S28 & 3 & 3 & 3 & 4 & 3 & 16 & $\begin{array}{l}\text { Blm } \\
\text { Tuntas }\end{array}$ \\
\hline & JUMLAH & 121.00 & $\begin{array}{c}108.0 \\
0 \\
\end{array}$ & $\begin{array}{c}115.0 \\
0\end{array}$ & 111.00 & 120.00 & 575 & \\
\hline & $\begin{array}{l}\text { RATA- } \\
\text { RATA }\end{array}$ & 4.32 & 3.86 & 4.11 & 3.96 & 4.29 & $\begin{array}{c}20.5 \\
4\end{array}$ & \\
\hline & $\begin{array}{c}\text { Presentase } \\
(\%)\end{array}$ & $86 \%$ & $77 \%$ & $82 \%$ & $79 \%$ & $86 \%$ & $82 \%$ & $85,7 \%$ \\
\hline
\end{tabular}

Pelaksanaan tindakan terdiri dari dua siklus yaiu siklus I dan II. Siklus I mendeskripsikan penerapan metode mind mapping pada siswa kelas VIII D SMP Negeri 5 Banguntapan dapat dikatakan berhasil meningkatkan kualitas proses dan hasil. Peningkatan kualitas proses dapat dilihat dari suasana pembelajaran yang lebih menyenangkan dan siswa lebih antusias dalam pembelajaran. Siswa senang dan bekerja dengan kertas dan spidol 
warna-warni serta menuangkan ide dalam gambar-gambar. Hal ini sesuai dengan manfaat dari mind mapping antara lain untuk mendapatkan ide, berkonsentrasi, , mengatur pikiran dan hobi, media bermain, bersenang-senang dalam menuangkan imajinasi yang tentunya memunculkan kreativitas (Jumanto, 2010). Setelah siswa diberi sebuah tema oleh guru, maka ia menuliskannnya di tengah-tengah kertas masing-masing. Siswa bersemangat dalam diskusi memilih kata-kata yang sesuai dengan tema untuk dituang dalam mind mapp puisi mereka. Siswa juga kreatif mengembangkan kata-kata berikutnya sebagai cabang dari poinpoin penting tema utamanya. Selanjutnya dari kumpulan kata-kata yang berhubungan satu sama lain tersebut siswa menyusun dan mengkreasikan menjadi sebuah puisi yang padu dan indah.

Kelemahan pada siklus I adalah:1) pangaturan alokasi waktu belum sesuai yang direncanakan, 2) masih ada beberapa siswa yang yang belum berperan aktif pada kegiatan diskusi kelompok, 3) masih ada beberapa siswa yang belum serius ketika menulis puisi sehingga tidak bisa menyelesaikan tugas sesuai waktu yang ditentukan, 4) guru belum sempat memberikan balikan dan penguatan puisi karya semua siswa karena keterbatasan waktu, 5) Skor aspek diksi dan persajakan siswa masih tergolong paling rendah daripada aspek lainnya.

Siklus II dilaksanakan untuk mengatasai kelemahan atau kekurangan yang ada pada siklus I. Dalam pelaksanaan siklus II kelemahan dalam proses pembelajaran siklus I dapat diatasi oleh guru dengan cara: 1) melaksanakan langkah-langkah pembelajaran sesuai dengan alokasi waktu yang direncanakan, 2) materi lebih ditekankan pada aspek diksi dan persajakan, 3) guru membentuk kelompok dengan kemampuan yang heterogen disetiap kelompoknya dan ketika diskusi kelompok guru berkeliling memberi motivasi dan bimbingan, 4) guru memberi bimbingan secara individu dalm proses menulis puisi dan memberikan perhatian lebih pada siswa tertentu yang belum serius mengerjakan puisi 5) guru memberikan balikan dan penguatan puisi semua siswa ,6) guru memberi batasan waktu yang jelas ketika memberi tugas.

Dari pelaksanaan tindakan yang terdiri atas siklus I dan siklus II pembelajaran menulis puisi dengan metode mind mapping dapat meningkatkan kualitas proses dan hasil pembelajaran menulis puisi. Berikut ini dijabarkan hasil penelitian yang meliputi kualitas pembelajaran dan keterampilan menulis puisi siswa kelas VIII D SMP Negeri 5 Banguntapan Bantul.

\section{Kualitas Pembelajaran Menulis Puisi}

Tindakan-tindakan berupa penerapan metode mind mapping (peta pikiran) yang dilaksanakan dalam tiap siklus mampu meningkatkan kualitas pembelajaran menulis puisi siswa kelas VIII D SMP Negeri 5 Banguntapan, Bantul. Hal ini dapat dilihat pada indikatorindikator berikut:

a. Keaktifan Siswa

Keaktifan siswa dalam pembelajaran menulis mengalami peningkatan. Peningkatan ini terlihat dari antusias siswa untuk bertanya, menjawab pertanyaan dan mengerjakan tugas-tugas yang diberikan guru. Hal ini berbeda dari kondisi awal pembelajaran menulis puisi sebelum tindakan. Dari pantauan peneliti, keaktifan siswa pada pratindakan diindikasikan ada 35,7\% (10 siswa). Persentase ini masih termasuk dalam kategori kurang. Pada siklus I keaktifan siswa mengalami peningkatan cukup signifikan yaitu sebesar $25 \%$. Dibandingkan dengan sebelumnya, siswa yang aktif pada siklus II ini mencapai 17 siswa atau sebesar 60,7, dari kategori kurang menjadi kategori baik. Siswa sudah berani bertanya serta menanggapi pertanyaan yang diajukan guru. Pada siklus II terjadi peningkatan sebesar 10,7\%, dari 17 siswa yang aktif pada siklus I menjadi 20 siswa $(71,4 \%)$, dengan kategori baik. Secara lebih jelas peningkatan aspek keaktifan siswa tersebut dapat dilihat pada grafik berikut. 


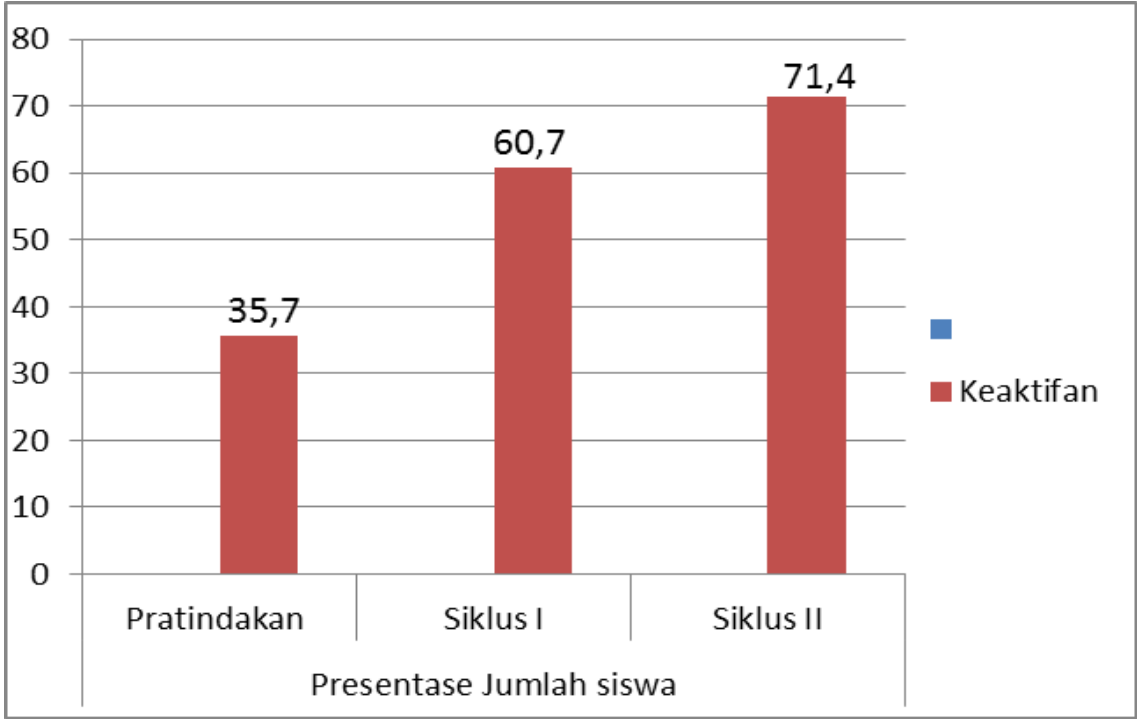

Gambar 1. Grafik Peningkatan Keaktifan Siswa dari Pratindakan, Siklus I, dan Siklus II

b. Perhatian dan Konsentrasi Siswa

Setelah dilakukan tindakan dengan menerapkan metode mind mapping, siswa tampak memperhatikan dan berkonsentrasi dalam pembelajaran menulis puisi. Desain pembelajaran yang disusun dalam proses pembelajaran menulis puisi dengan metode mind mapping mampu meminimalisir siswa untuk tidak melamun, tidak beraktivitas sendiri, tetapi mengikuti pembelajaran dengan menyenangkan. Dari pantauan peneliti pada siklus I, aspek perhatian dan konsentrasai mengalami kenaikan sebesar 32,1\% yaitu dari pratindakan sebesar 35,7\% (10 siswa) menjadi 67,9\% (19 siswa). Pada siklus II mengalami peningkatan sebesar 17,9\% yaitu dari siklus I sebesar 67,9\% (19 siswa) menjadi $85,7 \%$ (24 siswa). Pada pratindakan masih dalam kategori kurang, pada siklus I meningkat menjadi kategori baik, dan kategori baik sekali pada siklus II. Secara lebih jelas peningkatan aspek perhatian dan konsentrasi siswa terlihat dalam grafik berikut.

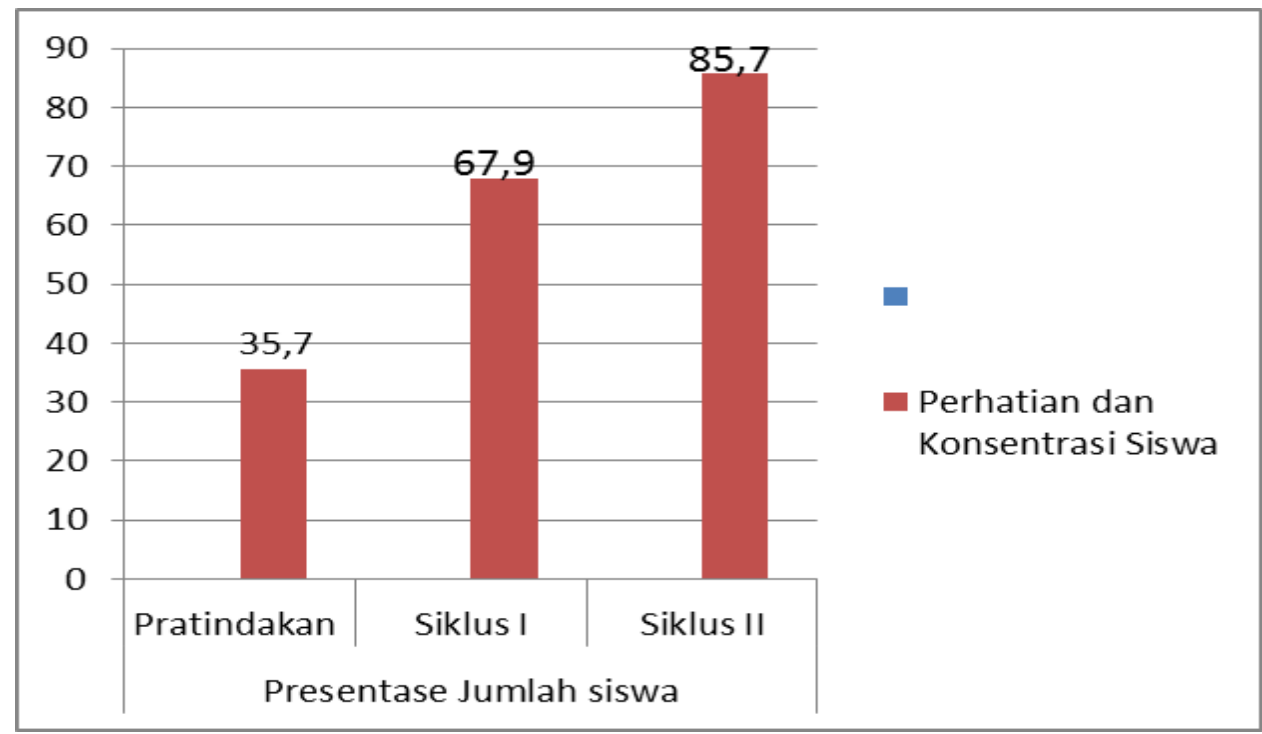

Gambar 2. Grafik Peningkatan Perhatian dan Konsentrasi Siswa dari Pratindakan, Siklus I, dan Siklus II 
c. Antusias Siswa Selama Pembelajaran

Dalam pelaksanaan pembelajaran menulis puisi dengan metode mind mapping siswa tampak senang dan antusias mengikuti pembelajaran. Siswa bersemangat dan memperlihatkan kesungguhan baik ketika melakukan diskusi kelompok ataupun mengerjakan tugas individu. Hal ini tidak terlepas dari meningkatnya kemampuan guru dalam mengelola kelas khususnya penggunaan teknik-teknik untuk memotivasi siswa. Dari pengamatan peneliti, pada siklus I sebanyak 15 siswa (53\%) dari 28 siswa antusias mengikuti pembelajaran menulis puisi. Jumlah ini mengalami peningkatan sebesar $17,9 \%$ pada siklus II sebesar yaitu menjadi 22 siswa (78,6\%). Peningkatan ini cukup signifikan jika dibandingkan pada prasiklus yaitu hanya 8 siswa (28\%) saja siswa yang antusias mengikuti pembelajaran . Secara lebih jelas peningkatan aspek antusias siswa selama pembelajaran terlihat dalam grafik berikut.

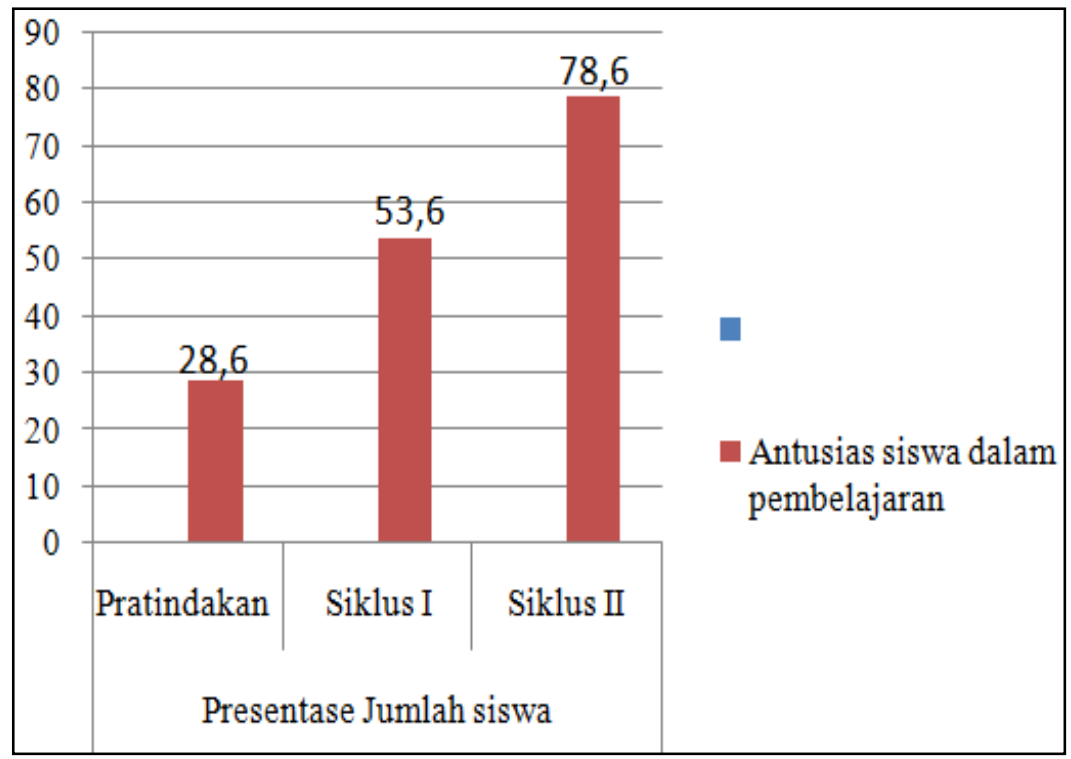

Gambar 3. Grafik Peningkatan Antusias Siswa dari Pratindakan, Siklus I, dan Siklus II

d. Keseriusan Siswa

Sebagaimana aspek keaktifan, perhatian dan konsentrasi serta antusias siswa, aspek keseriusan siswa saat kegiatan menulis puisi juga mengalami peningkatan. Siswa tampak serius ketika kegiatan menulis puisi. Pada waktu yang ditentukan, semua siswa bisa menyelesaikan puisinya. Hal ini tidak terlepas dari keterampilan guru memberi motivasi dan bimbingan secara individu dalam proses pembelajaran menulis puisi. Berdasar pantauan peneliti, pada siklus I mengalami peningkatan sebesar 21, 4\%, yaitu dari pratindakan sejumlah 13 siswa $(46,4 \%)$ menjadi 19 siswa $(67,9 \%)$. Aspek ini meningkat dari kategori cukup menjadi kategori baik. Pada siklus II jumlah siswa yang terindikasi serius meningkat menjadi 23 siswa $(82,1 \%)$. Aspek ini meningkat sebesar 14, 3\%, dari kategori baik menjadi baik sekali. Secara lebih jelas peningkatan aspek keseriusan siswa saat kegiatan menulis puisi terlihat dalam grafik berikut. 


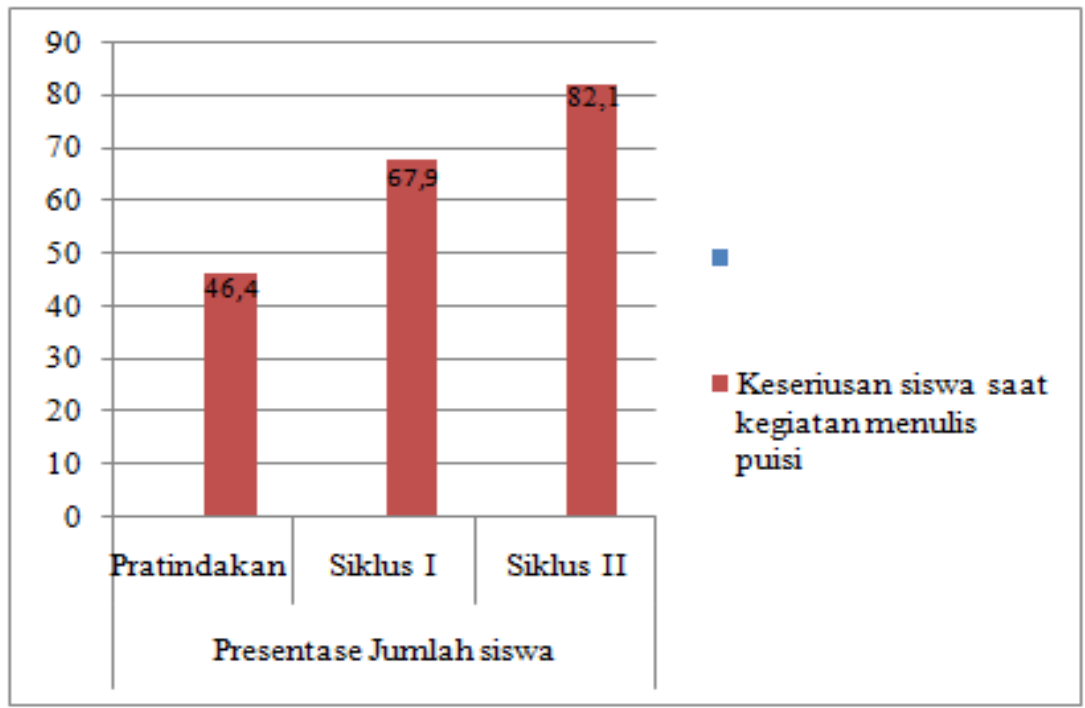

Gambar 4. Grafik Peningkatan Keseriusan Siswa dari Pratindakan, Siklus I, dan Siklus I

\section{Keterampilan Menulis Puisi Siswa.}

Peningkatan kualitas pembelajaran menulis puisi berimplikasi pada keterampilan menulis puisi siswa. Keterampilan menulis puisi juga mengalami peningkatan. Hal ini dapat dilihat dari peningkatan skor rata-rata hasil penilaian terhadap puisi siswa dari pratindakan, siklus I, dan siklus II sebagai berikut.

Tabel 5. Peningkatan Skor Rata-Rata Hasil Penilaian Puisi Siswa dari Pratindakan, Siklus I, dan Siklus II

\begin{tabular}{|l|l|c|c|c|c|c|}
\hline \multirow{2}{*}{ No } & \multirow{2}{*}{ Aspek } & \multicolumn{4}{|c|}{ Rata-rata } & Peningkatan \\
\cline { 3 - 5 } & $\begin{array}{l}\text { Pra } \\
\text { tindakan }\end{array}$ & $\begin{array}{c}\text { Siklus } \\
\text { I }\end{array}$ & $\begin{array}{c}\text { Siklus } \\
\text { II }\end{array}$ & Prentase \\
\hline 1. & $\begin{array}{l}\text { Kesatuan } \\
\text { makna }\end{array}$ & 3.21 & 4.14 & 4.32 & 1.11 & $34 \%$ \\
\hline 2 & Diksi & 2.71 & 3.39 & 3.86 & 1.14 & $42 \%$ \\
\hline 3. & Persajakan & 2.96 & 3.89 & 4.11 & 1.14 & $39 \%$ \\
\hline 4. & $\begin{array}{l}\text { Gaya } \\
\text { Bahasa }\end{array}$ & 2.96 & 3.64 & 3.96 & 1.00 & $34 \%$ \\
\hline 5. & Pencitraan & 3.04 & 4.07 & 4.29 & 1.25 & $41 \%$ \\
\hline & JUMLAH & 15.04 & 19.14 & 20.54 & 5.50 & $37 \%$ \\
\hline & Persentase & $60 \%$ & $77 \%$ & $82 \%$ & & \\
\hline
\end{tabular}

Berdasarkan tabel 5 dapat diketahuai skor rata -rata siswa dalam menulis puisi adalah 15, 04 atau $60 \%$ pada pratindakan, meningkat menjadi 19,14 atau $77 \%$ pada siklus I, dan pada siklus II meningkat menjadi 20, 54 atau $82 \%$. Skor rata-rata siswa dalam menulis puisi dari pratindakan sampai siklus II mengalami peningkatan sebesar 5,50 atau $37 \%$.

Ada pun penjabaran peningkatan tiap aspek yang menjadi indikator meningkatnya keterampilan menulis puisi siswa adalah sebagai berikut.

\section{a. Kesatuan makna}

Dari puisi karya siswa pada pratindakan diketahui bahwa kemampuan siswa dalam memilih judul dan tema sesuai dengan isi puisi masih dalam kriteria cukup. Setelah diterapkan tindakan pada siklus I, kemampuan siswa dalam memilih judul dan tema sesuai dengan isi puisi meningkat menjadi baik. Peningkatan pada siklus II ditandai dengan bertambahnya jumlah siswa yang mampu dalam memilih judul dan tema sesuai dengan isi puisi. Dari 28 siswa, yang mendapat kriteria sangat baik ada 11 siswa, kriteria 
baik ada 15 siswa, dan kriteria cukup ada 2 siswa. Sementara pada siklus I jumlah siswa yang mendapat kriteria sangat baik hanya 7 siswa, kriteria baik hanya 18 siswa, 3 siswa dengan kriteria cukup.

\section{b. Diksi}

Kemampuan siswa dalam aspek diksi paling rendah dibandingkan aspek yang lain . Hal ini sesuai hasil wawancara pada survei awal bahwa mereka kesulitan memilih katakata sesuai dengan tema. Pada pratindakan teridikasi para siswa kurang mampu memilih kata-kata yang tepat untuk menyampaikan makna puisinya. Setelah diterapkan tindakan pada siklus I siswa cukup baik atau cukup mampu memilih kata-kata yang tepat. Peningkatan pada siklus II ditandai dengan bertambahnya jumlah siswa yang mampu dalam memilih kata-kata yang tepat. Dari 28 siswa, yang mendapat kriteria sangat baik ada 2 siswa, kriteria baik ada 20 siswa, dan kriteria cukup ada 3 siswa. Sementara pada siklus I jumlah siswa yang mendapat kriteria sangat baik ada 2 siswa, kriteria baik hanya 9 siswa, 15 siswa dengan kriteria cukup, dan masih ada 2 siswa dalam kriteria kurang.

\section{c. Persajakan}

Dari puisi karya siswa pada pratindakan diketahui bahwa siswa rata-rata kurang mampu menimbulkan sajak yang merdu dari puisi yang dihasilkan. Hal ini terlihat dari skor yang diperoleh. 12 siswa memperoleh skor 2 dengan kriteria kurang, 6 siswa memperoleh skor 3 dalam kriteria cukup dan 10 siswa dengan skor 4 masuk kriteria baik. Setelah diterapkan tindakan pada siklus I, kemampuan siswa dalam perasajakan meningkat cukup signifikan . Pada siklus ini sebagian siswa sudah mampu menimbulkan sajak yang merdu dari puisinya, sebagian lain sudah sedikit mampu menimbulkan sajak. Pada siklus II terjadi peningkatan yaitu rata-rata siswa sudah mampu menimbulkan sajak yang merdu dari puisinya. Peningkatan pada siklus II ditandai dengan bertambahnya jumlah siswa yang mampu dalam menimbulkan sajak yang merdu pada puisinya. Dari 28 siswa, yang mendapat kriteria sangat baik ada 7 siswa, kriteria baik ada 17 siswa, dan kriteria cukup ada 4 siswa. Sementara pada siklus I jumlah siswa yang mendapat kriteria sangat baik hanya 3 siswa, kriteria baik 19 siswa, 6 siswa dengan kriteria cukup.

\section{d. Gaya Bahasa}

Pada pratindakan rata-rata hasil puisi siswa pada aspek gaya bahasa masih tergolong kurang karena siswa belum mampu menggunakan bahasa kias dengan baik. Sesudah penerapan metode mind mapping pada siklus I, hasil puisi siswa menunjukkan rata-rata siswa dalam aspek gaya bahasa meningkat. Rata-rata siswa sudah cukup baik dalam menggunakan bahasa kias. Peningkatan siklus II ditandai dengan bertambahnya jumlah siswa yang sudah mampu menggunakan bahasa kias dengan baik. Dari 28 siswa, jumlah siswa yang mendapat kriteria sangat baik ada 4 siswa, kriteria baik ada 19 siswa, dan kriteria cukup ada 5 siswa. Sementara pada siklus I jumlah siswa yang mendapat kriteria sangat baik hanya 4 siswa, kriteria baik 18 siswa, 7 siswa dengan kriteria cukup, dan masih ada 2 siswa dalam kriteria kurang.

\section{e. Pencitraan}

Aspek pencitraan berkaitan dengan penggunaan kata dalam memunculkan imajinasi, daya khayal, dan daya kreatif sehingga dapat menghasilkan puisi yang indah. Pada pratindakan para siswa cukup baik/sedikit mampu menggunakan citraan dengan baik. Setelah dilakukan tindakan pembelajaran menulis puisi dengan metode mind mapping pada siklus I, siswa sudah mampu menggunakan citraan dengan baik . Pada siklus II jumlah siswa yang memperoleh kriteria sangat baik pada aspek pencitraan ini meningkat cukup signifikan. Dari 28 siswa, jumlah siswa yang mendapat kriteria sangat baik ada 11 siswa, kriteria baik ada 14 siswa, dan kriteria cukup ada 3 siswa. Sementara pada siklus I jumlah siswa yang mendapat kriteria sangat baik hanya 6 siswa, kriteria baik 18 siswa, 4 siswa dengan kriteria cukup. 
KKM ( Kriteria Ketuntasan Minimal) yang telah ditetapkan SMP Negeri 5 Banguntapan adalah 75. Sebelum tindakan dilakukan siswa yang nilainya mencapai KKM sejumlah 12 dari 28 siswa atau 43\%. Setelah diadakan tindakan pada siklus I, jumlah siswa yang mencapai KKM meningkat menjadi 19 siswa atau 67,8\%. Pada akhir pelaksanaan siklus II jumlah siswa yang mencapai KKM meningkat menjadi 24 siswa atau 85,7\%.

Hasil penelitian ini sejalan dengan hasil penelitian yang dilakukan oleh Wahyu Sulistiyana (2011). Dalam penelitiannya, Wahyu Sulistiyana menunjukkan adanya peningkatan kemampuan pada proses dan hasil belajar dengan menggunakan metode Mind Mapping. Hal itu ditandai dengan meningkatnya nilai rata-rata siswa. Pada pratindakan nilai rata-rata 68,44 tingkat ketuntasan klasikal 41,18\%. Pada siklus I, nilai rata-rata 71,65 tingkat ketuntasan klasikal 82, 35\%. Pada siklus III, nilai rata-rata 78,88 tingkat ketuntasan 100\%. Penelitian ini dilakukan pada peserta didik kelas VIII A, SMP Negeri 4 Sukoharjo tahun pelajaran 2011/2012

Secara praktis, berdasarkan penelitian ini, pengunaan metode mind mapping dalam pembelajaran bahasa Indonesia memiliki potensi untuk dikembangkan guna meningkatkan kemampuan menulis puisi siswa. Dari hasil dan tanggapan siswa juga menunjukkan bahwa penggunaan metode mind mapping memberi kesan yang baik pada siswa. Metode mind mapping sebagai metode pembelajaran bahasa Indonesia, dapat mengubah suasana kelas dalam pembelajaran bahasa Indonesia menjadi lebih variatif dan menyenangkan . Akan tetapi, melihat ada beberapa siswa tidak mencapai ketuntasan belajar, penerapan metode mind mapping ini perlu memperhatikan perbedaan individual, kemampuan, dan minat siswa. Bagi siswa yang tergolong "slow learner", penerapan metode mind mapping (peta pikiran) perlu diimbangi bimbingan intensif dari guru.

Tarigan (1986: 21), menyatakan bahwa menulis adalah menurunkan atau melukiskan lambang-lambang grafik yang menggambarkan bahasa yang dipahami oleh seseorang, sehingga orang lain dapat membaca lambang-lambang grafik tersebut kalau mereka memahami bahasa dan grafik itu. Artinya, bahwa menulis merupakan suatu kegiatan yang tidak hanya sekadar menggambarkan simbol-simbol grafis secara konkret, tetapi juga menuangkan ide, gagasan, atau pokok pikiran ke dalam bahasa tulis yang berupa rangkaian kalimat yang utuh, lengkap, dan dapat dikomunikasikan kepada orang lain. Jadi, menulis merupakan keterampilan berkomunikasi antarkomunikan dalam usaha menyampaikan informasi dengan media bahasa tulis.

Tujuan menulis menurut Hartig (via Tarigan 1986: 25-26), "ada 6 yakni (1) Assignment Purpose (tujuan penugasan), (2) Altruistic Purpose (tujuan altruistik),(3) Persuasive Purpose (tujuan persuasif), (4) Informational Purpose (tujuan informasi, tujuan penerangan), (5) Self-Expressive Purpose (tujuan pernyataan diri), dan (6) Creative Purpose (tujuan kreatif)". Dalam trisula pengajaran sastra yang terdiri dari aspek apresiasi rekreasi dan re-kreasi ( Asep Yudha Wirajaya, 2005:85), menulis puisi merupakan bagian dari konsep rekreasi yang berarti kembali untuk menciptakan suatu karya sastra bukan sekadar membaca dan menikmati karya sastra. Penerapan metode pembelajaran harus memperhatikan konsep serta prinsip pembelajaran. Pada dasarnya pembelajaran bukan sekadar kegiatan transfer pengetahuan dari guru kepada siswa. Dalam pembelajaran, konteks diciptakan secara nyata sehingga siswa tidak hanya memperoleh pengetahuan tetapi pengalaman dan keterampilan.

Penilaian yang dipakai untuk mengukur kemampuan menulis puisi siswa berupa tes menulis puisi. Hasil penulisan puisi tersebut kemudian dinilai menggunakan rubrik penilaian menulis puisi. Rubrik dapat dipahami sebagai sebuah skala penyekoran (scoring scale) yang dipakai untuk menilai subjek didik untuk tiap kriteria terhadap tugas-tugas tertentu (Mueler dalam Nurgiyantoro, 2014:313).

Tingkat capaian kinerja, umumnya ditunjukkan dalam angka-angka dan yang lazim adalah 1-4 atau 1-5, besar kecilnya angka sekaligus menunjukkan tinggi rendahnya capaian . Tiap angka tersebut biasanya memunyai deskripsi verbal yang diwakili, misalnya skor 1: tidak ada kinerja atau kinerja tidak tepat sama sekali, skor 5: kinerja sangat meyakinkan dan 
bermakna, sedang skor 2, 3, 4 secara berturut-turut menunjukkan semakin baiknya kinerja dan kebermaknaannya. Bunyi deskripsi verbal haruslah sesuai dengan rubrik yang akan diukur. Penilaian tingkat kinerja seorang pembelajar dilakukan dengan menandai angka-angka yang sesuai. Rubrik lazimnya ditampilkan dalam tabel, kriteria ditempatkan di sebelah kiri dan tingkat capaian di sebelah kanan tiap kriteria.

Untuk anak-anak, peta pikiran (mind mapping) memiliki manfaat, yaitu: membantu dalam mengingat, mendapatkan ide, menghemat waktu, berkonsentrasi, mendapatkan nilai yang lebih bagus, mengatur pikiran dan hobi, media bermain, bersenang-senang dalam menuangkan imajinasi yang tentunya memunculkan kreativitas (Jumanto, 2010).

Langkah-langkah yang dapat dilakukan dalam menulis puisi dengan menggunakan metode mind mapping adalah sebagai berikut :

1) tentukan tema yang akan digunakan dengan menggunakan huruf kapital.

2) kembangkan tema tersebut dengan cara memetakan pikiran;

3) pilihlah kata-kata yang sesuai dengan tema .

4) pergunakanlah majas agar puisi menjadi lebih menarik;

5) Pergunakan warna yang sama utuk satu alur pemetaan agar nanti mempermudah dalam merangkai kalimat.

6) Pemetaan pikiran dapat menggunakan simbol atau gambar agar lebih menarik;

7) setelah pembuatan mind mapp atau kumpulan kata dirasa cukup, tulislah puisi sesuai dengan hasil pemetaan pikiran yang dibuat dengan cara menghubung-hubungkan kata-kata yang ada untuk disusun menjadi sebuah kalimat puitis.

8) Dari kalimat-kalimat puitis itu susunlah menjadi sebuah puisi.

Penilaian kualitas proses pembelajaran menulis puisi dimaksudkan untuk menilai aktivitas siswa dalam pembelajaran menulis puisi. Untuk melakukan penilaian, terlebih dahulu harus ditentukan aspek-aspek yang dinilai. Penilaian kualitas proses dalam penelitian ini akan dilihat dari faktor siswa dan guru. Dari faktor siswa terutama yang akan dicermati adalah aktivitas siswa dalam pembelajaran yang terdiri keaktifan, perhatian dan konsentrasi siswa, minat siswa dalam pembelajaran, serta keseriusan siswa saat menulis puisi. Sedangkan dari pihak guru akan dilihat apakah guru sudah melaksanakan pembelajaran sesuai dengan prinsip- prinsip pembelajaran dan skenario yang sudah disusun ( Dimyati dan Mudjiono, 2002:42-50).

Adapun cara yang digunakan untuk menentukan kualitas pembelajaran dalam penelitian ini adalah dengan observasi aktivitas siswa dan catatan lapangan selama berlangsungnya proses pembelajaran. Lembar observasi aktivitas siswa dengan aspek pengamatan yang terdiri: keaktifan, perhatian dan konsentrasi, Antusias, dan keseriusan siswa saat kegiatan menulis puisi.

\section{KESIMPULAN}

Berdasarkan hasil penelitian dan pembahasan yang telah dikemukakan pada bab sebelumnya, maka dapat disimpulkan bahwa metode Mind Mapping dapat meningkatkan keterampilan menulis puisi pada siswa kelas VIII D SMP Negeri 5 Banguntapan Bantul, baik dari segi proses maupun hasil pembelajaran. Meningkatnya kualitas proses pembelajaran dapat dilihat melalui persentase aktivitas siswa yang terdiri dari aspek keaktifan, perhatian dan konsentrasi, antusias, dan keseriusan siswa saat pembelajaran. Pada pratindakan siswa yang aktif hanya sebesar $35,7 \%$, siswa yang perhatian dan konsentrasi sebesar 35,7\%, siswa antusias dalam pembelajaran sebesar $28,6 \%$, dan siswa yang serius saat kegiatan menulis puisi sebesar $46,4 \%$. Setelah diadakan tindakan siklus I persentase aktivitas siswa meningkat yaitu siswa yang aktif sebesar 60,7\%, siswa yang perhatian dan konsentrasi sebesar $67,9 \%$, siswa yang antusias dalam pembelajaran sebesar $53,6 \%$, dan siswa yang serius saat kegiatan menulis puisi sebesar $67,9 \%$. Pada siklus II siswa yang aktif sebesar $71,4 \%$, siswa yang perhatian dan konsentrasi sebesar $85,7 \%$, siswa yang antusias dalam pembelajaran sebesar $78,6 \%$, dan siswa yang serius saat kegiatan menulis puisi sebesar $82,1 \%$. 
Peningkatan hasil pembelajaran Metode mind mapping juga meningkatkan keterampilan menulis puisi siswa. Hal ini ditandai dengan meningkatnya skor rata-rata siswa dari pratindakan, siklus I, dan siklus II. Nilai rata-rata menulis puisi siswa pada pratindakan adalah sebesar 15,04 dengan ketuntasan klasikal 43\%. Pada siklus I meningkat menjadi 19,14 dengan ketuntasan klasikal 67,8\%, dan pada siklus II meningkat menjadi 20, 54 dengan ketuntasan klasikal $85,7 \%$. Terjadi peningkatan skor rata-rata puisi siswa dari pratindakan sampai dengan siklus II sebesar 5,50.

\section{DAFTAR PUSTAKA}

Arikunto, S. 2015. Penelitian Tindakan Kelas: Jakarta: Bumi Aksara

Asep Yudha Wirajaya. 2005. "Kreasi, Rekreasi dan Re-Kreasi Sastra: Sebagai Bahan dari Penulisan Kreatif” dalam Menuju Budaya Menulis . Yogyakarta: Tiara Wacana.

Buzan, Tony.2012. Buku Pintar Mind Mapp. Jakarta: Gramedia

Dimyati, Mudjiono. (2002) Belajar dan Pembelajaran. Jakarta: PT Rineka Cipta

Kemendikbud.2013.Permendikbud no 81 A Tahun 2013 . Jakarta: Kemendikbud.

Djuanda, Dadan. 2008.Pembelajaran Keterampilan Berbahasa Indonesia di Sekolah Dasar. Bandung: Pustaka Latifah

Jumanto. 2010. Meningkatkan Kemampuan Menulis Cerita Melalui Metode Mind Mapping pada Siswa Kelas IV SD Negeri Sondokan No. 11 Surakarta, Sripsi. Surakarta: tidak diterbitkan

Nurgiyantoro, Burhan. 2014. Penilaian Pembelajaran Bahasa Berbasis Kompetensi. Yogyakarta: BPFE

Sayuti, Suminto A. 2002. Berkenalan dengan Puisi. Yogyakarta: Gama Media.

Sulistiyana, Wahyu. 2011. Upaya Meningkatkan Keterampilan Menulis Cerita Pendek dengan Metode Mind Mapping (PTK pada Siswa Kelas VIII D SMP Negeri 4 Sukoharjo. Tesis. Surakarta: tidak diterbitkan.

Tarigan. 2008. Menulis Sebagai Keterampilan Berbahasa. Bandung: Angkasa.

Waluyo, Herman J. 1987. Teori dan Apresiasi Puisi. Jakarta: Erlangga. 